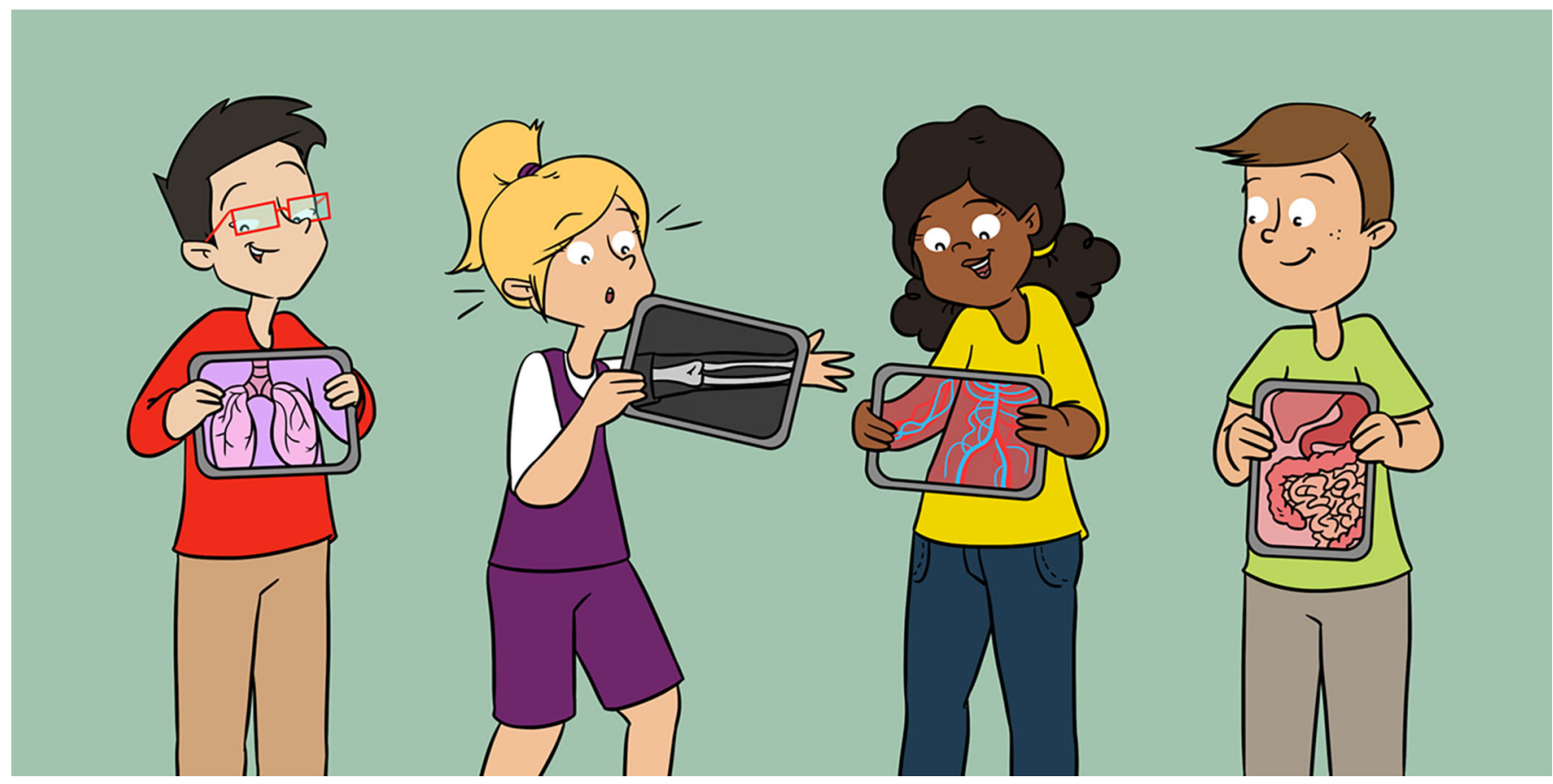

\title{
THE IMPORTANCE OF ANATOMY
}

\section{Kelly Stanford ${ }^{1}$, Sharon Rutland ${ }^{2}$, Craig J. Sturrock ${ }^{3+}$ and Catrin Sian Rutland ${ }^{4 * t}$}

${ }^{1}$ Energy and Environment Institute, University of Hull, Kingston upon Hull, United Kingdom

${ }^{2}$ Teacher and Independent Copyeditor, Derby, United Kingdom

${ }^{3}$ Hounsfield Facility, School of Biosciences, University of Nottingham, Nottingham, United Kingdom

${ }^{4}$ School of Veterinary Medicine and Science, University of Nottingham, Nottingham, United Kingdom

\section{YOUNG REVIEWERS:}

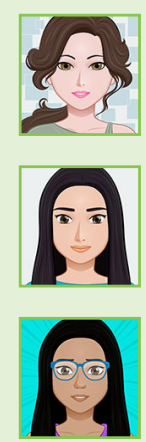

AMELIE

AGE: 12

HRISHIKA

AGE: 12

PRIYANKA

AGE: 12
Anatomy is the knowledge about the structure of the bodies of animals and people. This includes information about blood vessels, organs, the skeleton, and nerves. But have you ever wondered where the anatomical information in science books and websites comes from? When did our fascination with the body begin and why do people still study it now? Who teaches doctors, nurses, veterinary surgeons, and other health professionals about the body? How has anatomy inspired art, and vice versa? This paper looks at the amazing world of anatomy: what anatomy is; why it is needed; why it is important; who studies, teaches, and researches anatomy; and what the future holds for this fascinating science.

\section{WHAT IS ANATOMY?}

Anatomy is the study of the body's structure. It is a branch of science that investigates organs, bones, structures, and cells that 
Figure 1

(A) Microscopes are used to look at cells and tissues. (B) Real heart cells as viewed under a microscope. (C) Anatomists study bones and reassemble skeletons. (D) A real pygmy (mini) hippo skeleton. (E) Computed tomography (often called a CAT scan) is used to see inside animals and people. (F) Guinea-pig bones examined using computed tomography.

\section{PHYSIOLOGY}

The study of how normal living organisms function and work. For example how the human body and its organs functions.

\section{GROSS ANATOMY}

\section{Looking at}

structures/anatomy where you can see the objects using eyesight only, a microscope is not required.

\section{HISTOLOGY}

The study of cells and the body using a microscope.

\section{For more} information on blood vessels see our paper "Blood Vessels Under the Microscope" [1].
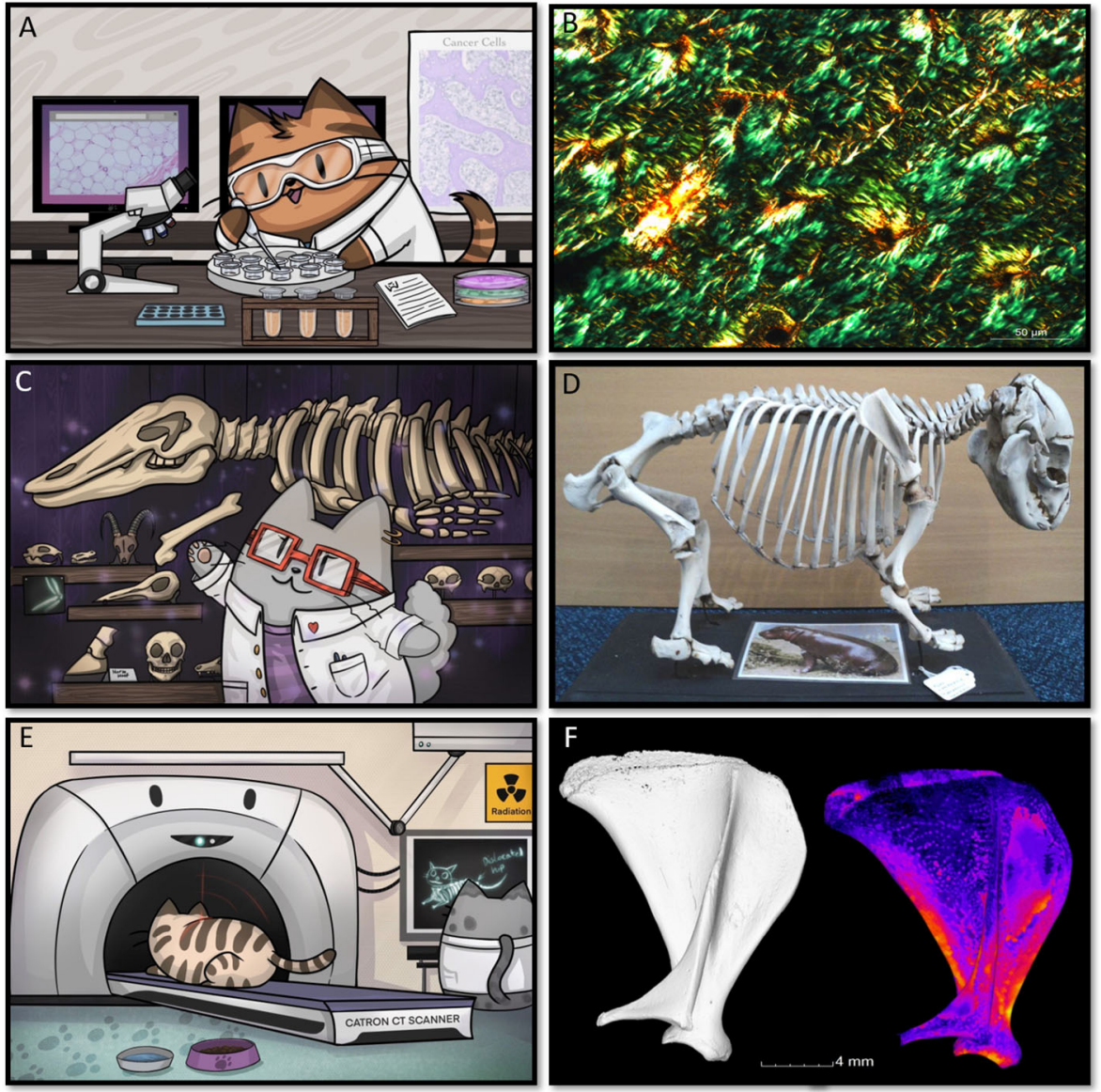

Figure 1

exist in animals and people. There is a related scientific discipline called physiology, which helps us to understand the functions of different parts of the body, but understanding anatomy is essential for physiology.

Anatomy is often split into two parts: gross anatomy, which involves investigating larger structures of the body, and histology (sometimes called microanatomy), which helps us understand the finer details of cells and smaller structures of the body. Equipment, such as microscopes (Figures 1A,B) are used for histology. Anatomy looks at embryos as well as both young and old animals and people. There are over 200 types of cells, with more still being discovered, and the average human body has 37.2 trillion cells. The human body also has around 640 named muscles, but this depends on how they are classified, so actually the total can be a lot more. Adults typically have 206-208 named bones and 100,000 miles worth of blood vessels (roughly the distance around the Earth four times). Children have 60,000 miles of blood vessels ${ }^{1}$. The body is very intricate and there is still much to study and learn about. 


\section{THE TEN BODY SYSTEMS}

Anatomists (researchers of anatomy) often split the body up into ten basic systems to help describe what different parts of the body do.

- Skeletal-The bones, cartilage, and joints.

- Muscular-The muscles, which helps the body move and breathe.

- Nervous-The brain, spinal cord, and cells called nerves that relay electrical impulses between the brain/spinal cord and the rest of the body.

- Respiratory-The lungs, nose, trachea, and other cells and tubes related to breathing.

- Cardiovascular-The heart, blood vessels, and blood, which provide oxygen and nutrients to the body and remove waste products.

- Lymphatic-Tubes called lymph vessels and several organs and cell types that drain away fluids and protect the body.

- Endocrine-Organs, such as the pancreas, liver, testes, and ovaries, and glands that produce/regulate hormones and other chemical signals.

- Male and Female Reproductive Systems-Organs involved in reproduction, including the uterus, clitoris, and penis.

- Urinary-The kidneys and bladder, which filter the blood, remove waste products, and produce and excrete urine.

- Digestive-Organs, such as the mouth, stomach, intestines, and anus, which digest and absorb food and dispose of waste products.

\section{RESEARCHING ANATOMY}

Throughout history there have been many great anatomists. It is hard to believe that we once did not know what the heart did or that red blood cells carry oxygen around the body. Even today we do not know or understand every part of the body. Anatomists play important roles in developing new technologies and techniques for looking at bodies.

Separating something into pieces, for example opening up a body or organ to see inside it.

\section{PATHOLOGIST}

A person who studies the causes and effects of diseases, often using bodies to diagnose illness or understand cause of death.
Historically, the best way of seeing inside the body was by dissection-cutting open the body to reveal its contents, a practice that is still done today. For example, if someone dies, a pathologist may need to discover the cause of death by looking inside the body, and surgeons need to cut open the body of the patient when they are doing surgery. The first well-known anatomists relied on dissection too. Although anatomy has been practiced for thousands of years, we are still learning more every day. New bones, muscles, blood vessels, cells, and functions are still being discovered by anatomists. 
Figure 2

Anatomy is often studied and taught using (A) skeletons, (B) models of blood vessels, and (C) organs, to help students research and understand the body and how it works. (D) $X$-rays can also be used to look inside the body.

(E) Anatomists often work alongside other types of scientists to investigate how the body works.

\section{COMPUTED}

\section{TOMOGRAPHY}

Also called CAT scan; a technique in which an object, person, or animal is imaged using many $X$-rays and the images are processed using computers.

\section{MAGNETIC \\ RESONANCE \\ IMAGING (MRI)}

Scanners use magnetic fields and radio waves to produce detailed 3D anatomical images (and images of other objects) without cutting the body open or using $\mathrm{x}$-rays.

2 If you want to see what guinea-pig bones look like using computed tomography, see our paper looking at bone growth and structure [2]. We have also done work using MRI to investigate how bones are involved with lameness in cattle [3].

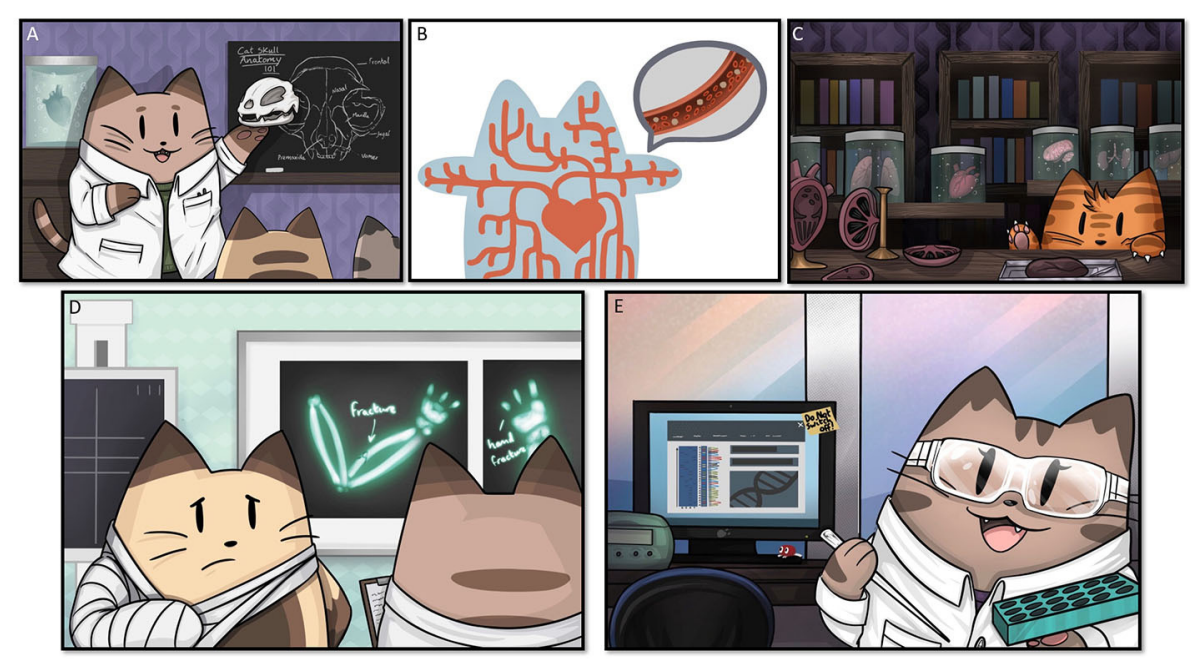

Figure 2

If you have been to a natural history museum, you may have seen skeletons prepared by skilled anatomists (Figures 1C,D, 2A). You may also have seen 3D models of the blood and/or lymph vessels in the body (Figure 2B). Models are also made of the entire body or certain body parts (Figure $2 \mathrm{C}$ ), to help others understand anatomy.

By the 1600s, microscopes were used to magnify organs and cells, giving even greater insight into what they look like and how they work. As technology advanced, more powerful microscopes were developed. We can now see objects thousands of times larger than their actual size.

By using modern technologies, such as computed tomography (also called CAT scans; Figures 1E,F), magnetic resonance imaging (MRI), and X-rays (Figure 2D), we can see inside the bodies of both living and dead organisms. These technologies reveal the inner body without the need to physically cut the body open ${ }^{2}$. These techniques not only help anatomists learn about the body, but they also help doctors to diagnose illness and understand a multitude of other medical problems.

Anatomists often use additional techniques to understand the function of the body. For example, they need to understand how genes work and how each cell and organ functions (Figure 2E). Anatomists often work with other scientists and doctors to understand how medicines and different diseases affect the body, which can help identify treatments and cures for diseases. They also work with pathologists, with forensic scientists who use science to help solve crimes, with paleontologists who look at fossils, and with archaeologists trying to uncover reasons for death or extinction. 


\section{TEACHING ANATOMY}

There are many types of people who teach anatomy and also many people who need to learn it. Learning about the body often begins at nursery and school. Songs, such as "heads, shoulders, knees, and toes" help young children to learn the names of their body parts. We also learn about organs, such as the brain and heart and how to maintain a healthy lifestyle to keep our bodies fit and active. School science teachers often teach anatomy. You can even take a university/college degree in anatomy. If you are studying biology, medicine, veterinary medicine, nursing, midwifery, physiotherapy, or several other health-related fields, you will be taught anatomy. After all, no one can do surgery without knowing where all the organs, bloods vessels, muscles, and other parts of the body are located. Top athletes, their coaches, those who give massages, and sports therapists also need to learn the parts of the body and how they work. If you take sports qualifications at school, you will probably learn about the bones and muscles involved in athletics.

\section{FAMOUS ANATOMISTS AND THE ARTS}

Throughout history, the body has been a source of inspiration not only for science but also for the arts. How many paintings, books, photographs, and sculptures have you seen of humans and animals? Even the very first cave people drew human bodies. Ancient Egyptians were working on the heart and blood vessels in $1600 \mathrm{BC}$. Around 400 BC, a Greek man named Hippocrates became known as the father of medicine and a founder of anatomy (Figure 3A). Herophilus, who was also Greek but worked much of his life in Egypt, became known as the father of anatomy and was one of the first people known to dissect humans. A school of anatomy was set up in 300 BC in Alexandria, Egypt [4]. The first documented woman practicing anatomy and pathology was Alessandra Giliani in the 1300s, but it is likely there were many before her (Figure 3B). Women have long been doctors and midwives, even when it was banned or seen as outrageous. Likewise, many women have studied anatomy despite the views of society. In 1847, Dr. Elizabeth Blackwell was the first woman to attend medical school in the United States, and in 1864 Dr. Rebecca Lee Crumpler became the first African-American woman doctor. In the UK, in the 1860s, Dr. Elizabeth Garrett Anderson was the first openly female doctor, but before that Dr. James Barry also practiced medicine but she had to dress as a man and have a male name in order to do so. Luckily, today many anatomists and doctors are female.

Some anatomists have been artists, too. Leonardo Da Vinci combined art and science to help show what was inside the body, by creating brilliant pieces of art (Figure 3C). Anna Morandi Manzolini was another Italian anatomist and sculptor (Figure 3B). In the 1700s, she worked in her home laboratory, writing about the organs, teaching, and 
Figure 3

(A) Hippocrates, called the father of medicine, and Herophilus, who is called the founder of anatomy and who carried out the first recorded dissection, worked in ancient Greece around 400 BC.

(B) Sculptor Anna Morandi Manzolini worked in Italy in the 1700s, creating wax models and writing about organs and teaching in her home laboratory. The picture also shows Alessandra Giliani, who practiced anatomy in the 1300 s and is famous for dissection. (C)

Leonardo da Vinci was brilliant in many areas, but is well-known for being an anatomist, teacher, researcher, and artist. He had a great interest in the heart and blood vessels.
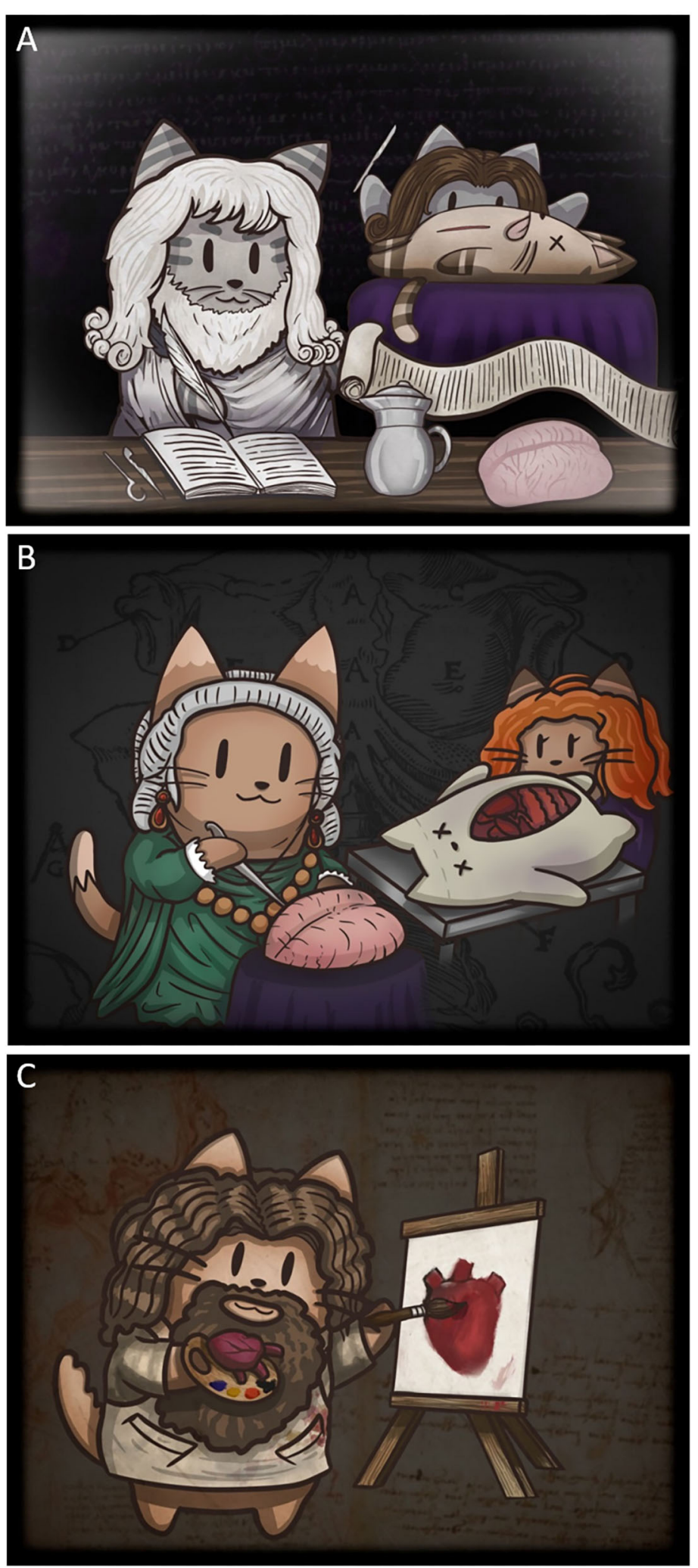

Figure 3

creating detailed wax models [5]. Florence Rena Sabin and many other anatomists followed her example and taught using models. 
Today, anatomists worldwide use models and 3D animations to help guide students.

Some people have also studied a little anatomy to create art pieces. For example, Mary Shelley wrote her brilliant novel "Frankenstein" at the age of just 18, back in the 1800s when it was seen as shocking for women to even wonder about how the body worked.

\section{CONCLUSIONS}

Today, we can visit museums and marvel at skeletons and wax models, learning science and appreciating the beauty of the human body. Anatomy is taught to most people at school and is not only important in medicine and sports, but is also an inspiration for art and literature worldwide. Today's anatomists combine many technologies and techniques to discover more about animals and humans, thus advancing the field of medicine.

\section{ACKNOWLEDGMENTS}

The authors would like to thank the Anatomical Society for helping to fund this work through a Public Engagement and Outreach grant to Catrin titled Anatomy for ALL-Making Anatomy Accessible. We would also like to thank the British Science Association and University of Nottingham for awarding Catrin with a BSA Media Fellowship 2019.

\section{REFERENCES}

1. Machado, M., Mitchell, C., Franklin, J., Thorpe, A., and Rutland, C. 2020. Blood vessels under the microscope. Front. Young Minds 8:151. doi: 10.3389/frym. 2019.00151

2. Witkowska, A., Alibhai, A., Hughes, C., Price, J., Klisch, K., Sturrock, C. J., et al. 2014. Computed tomography analysis of guinea pig bone: architecture, bone thickness and dimensions throughout development. Peerj 2:e615. doi: $10.7717 /$ peerj.615

3. Newsome, R., Green, M. J., Bell, N. J., Chagunda, M. G. G., Mason, C. S., Rutland, C. S., et al. 2016. Linking bone development on the caudal aspect of the distal phalanx with lameness during life. J. Dairy Sci. 99:4512-25. doi: 10.3168/jds. 2015-10202

4. Pearce, J. M. S. 2019. Early contribution of Alexandria medical school to the anatomy, physiology and pathology of the nervous system. Rev. Neurol. 175:119-25. doi: 10.1016/j.neurol.2018.04.011

5. Ferry, G. 2018. A woman's place Anna Morandi: anatomist of enlightenment Bologna. Lancet 392:375. doi: 10.1016/S0140-6736(18)31661-1 
SUBMITTED: 29 March 2020; ACCEPTED: 17 November 2020;

PUBLISHED ONLINE: 15 December 2020.

EDITED BY: Ajithkumar Vasanthakumar, Peter Doherty Institute for Infection and Immunity, Australia

CITATION: Stanford K, Rutland S, Sturrock CJ and Rutland CS (2020) The Importance of Anatomy. Front. Young Minds 8:546763. doi: 10.3389/frym.2020. 546763

CONFLICT OF INTEREST: The authors declare that the research was conducted in the absence of any commercial or financial relationships that could be construed as a potential conflict of interest.

COPYRIGHT @ 2020 Stanford, Rutland, Sturrock and Rutland. This is an open-access article distributed under the terms of the Creative Commons Attribution License (CC BY). The use, distribution or reproduction in other forums is permitted, provided the original author(s) and the copyright owner(s) are credited and that the original publication in this journal is cited, in accordance with accepted academic practice. No use, distribution or reproduction is permitted which does not comply with these terms.

\section{YOUNG REVIEWERS}

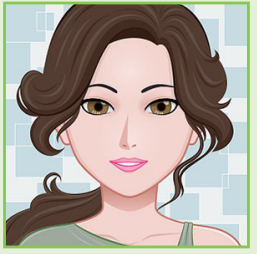

\section{AMELIE, AGE: 12}

I have been participating in Frontiers for Young Minds for the past 2 years. Reviewing papers is one of my passions as well as reading, painting, drawing, and writing. Through reading these scientific papers, I have learned a lot about health and disease. I love to travel and my favorite animal is the pangolin.
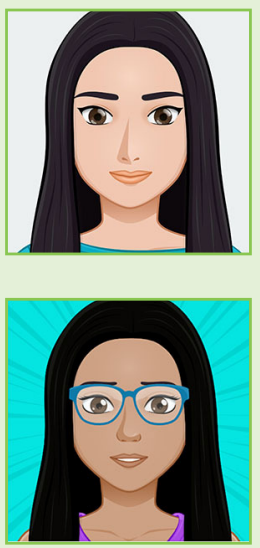

\section{HRISHIKA, AGE: 12}

I am Hrishika and I love animals. I like reading realistic fiction and I want to become a doctor when I grow up.

\section{PRIYANKA, AGE: 12}

My name is Priyanka and I enjoy reading, drawing, and imagining creative stories about fantasy and magic. My favorite animals are dragons and snakes and other reptiles. When I grow up I want to become a children's book author and illustrator.

\section{AUTHORS}

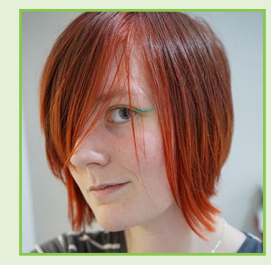

\section{KELLY STANFORD}

Kelly is a Manchester-based science communicator and artist currently researching how art and games can be used as tools for science outreach, as part of a M.Sc. at the University of Hull. She has collaborated with researchers all over the world, creating interdisciplinary projects that are used to communicate science to the public and inspire people to get involved in STEM. 

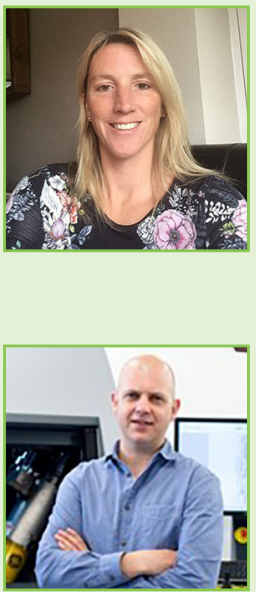

\section{SHARON RUTLAND}

I am a teacher and have taught young people in schools for over 20 years. I am also a professional proof-reader and copyeditor and more recently I have written my first children's novel. I have two children, Joshua and Erin, who love learning about animals and science. In my spare time, I enjoy playing tennis to keep fit and healthy.

\section{CRAIG J. STURROCK}

I am a co-director of the Hounsfield Facility at the University of Nottingham, with over 15 years' experience in the use of X-ray computed tomography. As a Principal Research Fellow, a major part of my work is the use of novel image analysis techniques to measure the microstructure of biomaterials ranging from animal bones to soils and plant roots. I love working with the latest technologies to understand the wonders of the natural world. Find out more here: https://www . nottingham.ac.uk/microct/. ${ }^{\dagger}$ orcid.org/0000-0002-5333-8502

\section{CATRIN SIAN RUTLAND}

I am Associate Professor of Anatomy and Developmental Genetics at the University of Nottingham and 2019 British Science Association Media Fellow. I lead a group of research scientists investigating why people and animals suffer from heart and blood vessel disorders, looking for techniques to detect, prevent, and cure. I fell in love with anatomy when I was very young, when my parents gave me an anatomy book to read. My parents and teachers all encouraged me to learn science and anatomy. I am very lucky to be able to teach and research anatomy every day now. I also enjoy traveling and writing science fiction. *catrin.rutland@nottingham.ac.uk †orcid.org/0000-0002-2009-4898 